\title{
\#EdTechHub
}

Realising the potential of technology in education

\section{EdTech in Nigeria: A Rapid Scan}

Opeyemi Dele-Ajayi and Abeba Taddese

EdTech Hub, https://edtechhub.org

Country Scan

2020-06-30

DOI: 10.5281/zenodo.3911651 


\section{About this document}

Recommende Dele-Ajayi, O., and Taddese, A. (2020). EdTech in Nigeria: A Rapid Scan. d citation. (EdTech Hub Country Scan No. 01). DOI: 10.5281/zenodo.3911651. Available from https://docs.edtechhub.org/lib/LE68WDS3. Available under Creative Commons Attribution 4.0 International, https://creativecommons.org/licenses/by/4.0/.

Licence. Creative Commons Attribution 4.0 International https://creativecommons.org/licenses/by/4.0/.

You - dear readers - are free to share (copy and redistribute the material in any medium or format) and adapt (remix, transform, and build upon the material) for any purpose, even commercially. You must give appropriate credit, provide a link to the license, and indicate if changes were made. You may do so in any reasonable manner, but not in any way that suggests the licensor endorses you or your use.

\section{Creative N/A \\ Commons \\ Acknow- \\ ledgement}

Identifiers. $\quad$ 2405685:LE68WDS3; $10.5281 /$ zenodo.3911651

Internal use. g/document/d/1BCQkyU82IBRs9TSIsQvBc3qBpbvrFR5kqMkWcNOT4F w/edit?ts $=5$ ef65925

Notes. You can contact the EdTech Hub here: https://edtechhub.org/hello/.

Reviewed by Dr Roni Ajao, Executive Director, MRL ${ }^{\circledR}$ Public Sector Consultants, Ltd.; Kate Jefferies, Education Advisor, DFID

Notes. The EdTech Hub is supported by UK aid from the UK government. The views expressed are the views of the authors and do not necessarily reflect views of our donors. 


\section{About this scan}

EdTech Hub country scans explore factors that enable and hinder the use of technology in education. This includes policies, government leadership, private-sector partnerships, and digital infrastructure for education. The scans are intended to be comprehensive but are by no means exhaustive; nonetheless, we hope they will serve as a useful starting point for more in-depth discussions about opportunities and barriers in EdTech in specific countries, in this case, Nigeria.

This report was originally written in June 2020. It is based primarily on desk research, with quality assurance provided by a country expert. Given how rapidly the educational technology landscape is evolving, the Hub plans to provide periodic updates. Table 1 provides a summary of the situation regarding EdTech in Nigeria.

\section{Table 1. EdTech in Nigeria}

\begin{tabular}{|l|l|}
\hline Policies & $\begin{array}{l}\text { - National ICT Policy (Ministry of Communication Technology, 2012) } \\
\text { - National Policy on ICT in Education (Federal Ministry of Education, } \\
\text { 2019b) }\end{array}$ \\
\hline Infrastructure & $\begin{array}{l}\text { - At the household level, mobile phones (88\%) and radios (61\%) are the } \\
\text { most prevalent technologies (USAID, 2018) In 2019,54\% of adult } \\
\text { males were mobile internet users compared to 38\% of adult females } \\
\text { (GSMA, 2020). } \\
\text { - Ownership of computers is very low, both in urban (13.4\%) and rural } \\
\text { areas (2.5\%) (USAID, 2018). }\end{array}$ \\
$\begin{array}{l}\text { - Approximately 65\% of primary and junior secondary schools lack } \\
\text { access to electricity (Lawal, 2017). }\end{array}$ \\
$\begin{array}{l}\text { - Only 39\% of rural households are connected to the national power } \\
\text { grid compared to 83\% of urban households (USAID, 2018). } \\
\text { - Data on the availability and access to computers and internet in } \\
\text { primary and secondary schools is not publicly available. }\end{array}$ \\
\hline $\begin{array}{l}\text { Partners and } \\
\text { initiatives }\end{array}$ & $\begin{array}{l}\text { - The Federal Ministry of Education (FME) has a key role in setting } \\
\text { policies that define the use of EdTech in education. } \\
\text { - The FME also works closely with the Federal Ministry of } \\
\text { Communications in relation to ICT provision, in addition to other } \\
\text { Federal Ministries, Departments and Agencies (MDA's). }\end{array}$ \\
\hline
\end{tabular}




\begin{tabular}{|l|l|}
\hline & $\begin{array}{l}\text { - The FME shares responsibility for implementing EdTech policy and } \\
\text { practice with concurrent education authorities at the federal and state } \\
\text { level such as the Universal Basic Education Commission (UBEC) and } \\
\text { State Universal Education Boards (SUBEBs). } \\
\text { - There is limited government funding for EdTech; nearly all EdTech } \\
\text { initiatives are led by NGOs, startups and international organisations. }\end{array}$ \\
\hline Covid-19 & $\begin{array}{l}\text { On March 19, 2020, the Nigerian FME closed all schools, affecting } \\
\text { about } 40 \text { million students throughout the country. } \\
\text { In April } 2020, \text { the FME and the Universal Basic Education Commission } \\
\text { (UBEC) launched a Learn at Home Programme and a contingency plan } \\
\text { as part of a Covid-19 National Coordinated Education Response for } \\
\text { Nigeria }\end{array}$ \\
\hline
\end{tabular}

\section{Country overview}

Nigeria is a major player in regional and global affairs buoyed by significant human and economic resource capacity. It is Africa's leading economy and the 30th largest economy in the world by GDP volume.

As the most populous country in Africa with over 190 million residents, Nigeria is known as the 'Giant of Africa'. The country has an annual population growth rate of $2.6 \%$ and a youthful population below the age of 15 that makes up $46 \%$ of the country's population (UNICEF, 2020). Over 250 ethnic groups are spread across 36 states and the Federal Capital Territory (United States Embassy in Nigeria, 2012). Government at the federal level is divided into three arms - the Executive, the Legislative and Judiciary; co-dependent on one another but functioning under the principle of separation of powers. The largest ethnic groups in Nigeria are the Hausa and Fulani. Together, they account for approximately 29\% of the country's population (ibid.). The Yoruba make up 21\%, while the Igbo account for $18 \%$ of the country's population (ibid.). The rest of Nigeria's population is spread across ethnic groups that include Ibibio, the Efik, the ljaw, the Annang, the Urhobo-Isoko, Edo and Itsekiri.

Nigeria is a lower-middle-income country that is large and richly endowed with natural resources. However, poverty remains a significant challenge, with $50 \%$ of citizens living below the poverty line, and high inequalities in income and opportunities (World Data Lab, 2020; World Bank, 2020). Nigeria currently ranks 152 out of 157 on the World Bank's Human Capital Index (World Bank, 2018). Poverty is disproportionately concentrated in the north (consisting of the north-west, north-east and north Central) - home to $87 \%$ of all the 
poor in the country and a region burdened by a lack of economic opportunities and persistent Boko Haram insurgency (Sattar \& Kalam Azad, 2019).

\section{Education system overview}

The 6th edition of the National Policy on Education 2013 describes the philosophy, objectives and goals that guide Nigeria's education sector (Nigerian Educational Research and Development Council, 2013). The FME is responsible for national-level policy formation and implementation and also has a supervisory role in ensuring the quality delivery of education services.

The Nigerian education system is structured as follows:

- Early childhood / pre-primary education - children aged 0-4 years.

- Basic education - free and compulsory education which includes six years of primary education and three years of junior secondary education. Junior secondary education is both pre-vocational and academic. Primary and junior secondary education levels also include adult and non-formal education programmes for adults and out-of-school youth.

- Post-basic education - three years of senior secondary education or technical and vocational education.

- Tertiary education - universities, colleges of education, polytechnics, monotechnics and institutions that offer correspondence courses.

The FME and state ministries of education share responsibilities for implementing education policy in Nigeria, with concurrent education authorities at both state and federal levels. For example, the Universal Basic Education Commission (UBEC) and State Universal Education Boards (SUBEBs) both administer the compulsory basic (primary and lower secondary) education policy (Outhred \& Turner, 2020).

The National Council on Education is responsible for educational policy formulation below the cabinet-level. The Council includes the Honourable Minister of Education, the 36 State Commissioners for Education, and the Joint Consultative Committee on Education (made up of education officials and experts). The Basic and Secondary Education Regulatory Commission ensures that the governments at all levels in Nigeria provide free, compulsory, and universal basic education for every child. The Tertiary Education Regulatory Commission is charged with regulating all federal-government-owned tertiary institutions in Nigeria. The National Education Resource Commission is tasked with effectively managing the resources (teachers, curriculum and administration) that are needed to ensure the success of the education sector in Nigeria. The Commission is also responsible for developing curricula for all levels of the educational system and training, upgrading, and certifying teachers at all levels.

Funding for education is also a shared responsibility between federal and state governments. At the state levels, basic education is funded from direct federal transfers to local government authorities, the Universal Basic Education Intervention Fund and state 
budgets (including federal transfers and locally generated revenues) (Outhred \& Turner, 2020). Although Nigeria is the largest economy in Africa, it invests less in education than many other African countries (The Nation, 2018). In the 2020 budget, Nigeria allocated 6.7\% of the total budget for education (Shamsuna Ahmed, 2020). Salaries, allowances, and social benefits take up $87 \%$ of this allocation; $5 \%$ is dedicated to overhead costs leaving $8 \%$ for capital projects. Each of the 36 states decides what percentage of their budget to allocate to education.

\subsection{Education sector progress and challenges}

The education system in Nigeria is at a crisis point with many of the states failing to achieve the goals set out by the federal government and other international indicators on education. The problems identified include:

- inadequate and often mismanaged government funds;

- inequality with regard to provision and access to educational opportunities;

- gender disparity;

- underqualified teaching staff;

- insufficient and inaccurate education planning;

- poor school management; dilapidated school structures;

- lack of ICT and an underdeveloped and overloaded curriculum;

- the lack of a uniform educational system, and limited teaching aids and resources that lead to a disconnect between the subjects taught within the curriculum and the needs of the labour market in the 21 st century.

These challenges are discussed in more depth below.

Notwithstanding these challenges, Nigeria's efforts to achieve progress in the education sector has gradually begun to deliver positive results. According to the Education for All 2015 National Review, there was a 98\% increase in children's access to and enrollment in public, pre-primary schools nationwide, a 10\% increase in enrollment in public primary schools and a 35\% increase in enrollment in public junior secondary schools between the years 2009 and 2013 (Federal Ministry of Education, 2015). Although these numbers appear impressive, the improvement in enrollment is not enough to keep up with the increase in the school-age population (UNESCO, 2015).

Further, gains in enrollment have been eroded by constant terrorist attacks in the north of Nigeria, which have forced large numbers of young people out of school. Globally, Nigeria now has the highest number of out-of-school children of primary age -13.5 million (USAID, 2015). Only $61 \%$ of children aged 6-11 regularly attend primary school and only $35.6 \%$ of children below five years of age receive some form of early childhood education (UNICEF Nigeria, 2020).

In the north of the country, getting out-of-school children back into schooling, especially girls, is a massive challenge. Further, in Northern Nigeria, the Almajiri education system which was set up to train children and youth in Qur'anic literacy is failing to deliver basic 
education to seven million students, who spend their time collecting alms to support their teachers' livelihoods (Ishaku \& Oraka, 2019). States in the north-east and north-west have female primary net attendance rates of $47.7 \%$ and $47.3 \%$, meaning that more than half of the girls are not in school (UNICEF Nigeria, 2019). Several other factors, including economic barriers and socio-cultural norms and practices that discourage attendance in formal education, and in the cases of the Almajiri system, a lack of integration with the formal education system, contribute to educational deprivation in Nigeria (ibid.; Ishaku \& Oraka, 2019).

Nigeria's educational challenges also include ensuring equitable access to schools and learning across gender, ethnic and regional lines (RISE, 2019), and among children with disabilities for whom official data is non-existent (Dark, 2018). An inadequate number of well-trained pre-primary teachers / caregivers and a shortage of qualified teachers, poor content knowledge, dilapidated structures and insecurity most notably in the Northern part of the country, continue to affect the learning outcomes of enrolled students. At both the federal and state levels, inadequate funding levels due to a misappropriation of allocated funds worsens these challenges. Even so, the real picture of states' spending on education is not always clear due to the lack of a monitoring and reporting culture.

Beyond the budgets, there is a general paucity of quality statistical data in the education sector (Nwoko, 2015). This poses a significant challenge for educational planning in Nigeria. The lack of data from the states makes it difficult to obtain an accurate understanding of progress, with international bodies and agencies having to depend on indicative substitutes during planning processes (Outhred \& Turner, 2020).

\subsection{Education Sector Plan 2018-2022}

The Education for Change: Ministerial Strategic Plan (2018-2022) aims to achieve strategic results around three major areas: Access, Quality and Systems Strengthening (Federal Ministry of Education, 2017). The results are built around Ten programmatic pillars that outline focus areas, strategies and activities for achieving results. These results and corresponding pillars are:

1. Access: Enhanced capacity of Nigeria's formal and non-formal education systems that provide access in the following ways - to 100 per cent of out-of-school and school-age children, boys and girls in basic education; to 70 per cent of eligible youths in TVET and tertiary education; and to 75 per cent of adults in non-formal education and lifelong learning opportunities.

a. Pillar 1 - Out-of-school children

b. Pillar 2 - Youth and adult literacy

c. Pillar 3 - Science, Technology, Engineering and Mathematics (STEM) and Technical, Vocational Education and Training (TVET)

2. Quality: Strengthened human capacity for child-centred interactive teaching and quality assurance at all levels of educational development in Nigeria, enhanced 
innovativeness, functionality, relevance, market-driven knowledge and skills acquisition, and transitioning into formal and non-formal education.

a. Pillar 4 - Basic education

b. Pillar 5 - Teacher education, capacity building and professional development

c. Pillar 6 - Curriculum and policy matters

d. Pillar 7 - Tertiary education

3. Systems Strengthening: Improved evidence-based decision making that will assist transparency, governance, accountability and innovation in education delivery.

a. Pillar 8-Education data and planning

b. Pillar 9 - Information and Communication Technology (ICT) in education

c. Pillar 10 - Library services in education. 


\section{EdTech policy and strategy}

In this section, we describe Nigeria's national ICT policy and include a brief look at the ICT in education policy.

\subsection{National policy}

The National ICT Policy seeks to fully integrate information and communication technology into the socio-economic development of Nigeria and transform it into a knowledge-based economy (Ministry of Communication Technology, 2012). The policy organises the sector for performance and efficiency in achieving the development goals stated in the country's economic transformation plan - Nigeria Vision 20:2020 (Federal Government of Nigeria, 2010). The Vision 20:2020 plan highlights the role of ICT in development in sectors that also include agriculture, oil and gas, health, finance, governance, infrastructure support, knowledge-based economy, labour employment and productivity, and research and development.

\subsection{ICT in education policy}

The National Council on Education and the Federal Executive Council approved the National Policy on Information and Communication Technologies in Education (ICT) document for the development and deployment of ICT in education in 2010 (Federal Ministry of Education, 2019b). Advancements in education and technology prompted a review of the policy, which was updated and launched in 2019.

The policy is linked directly to several national instruments like the national vision, the national policy on education, the national information technology education framework, and the ministerial strategic plan. The policy development process followed broad consultation and collaboration with federal education departments, other federal ministries, state ministries of education, IT professional bodies, private sector, non-governmental organisations, and some international development partners. It identifies seven focus areas:

1. Human Capital Development

2. Infrastructure

3. Research and Development

4. Awareness and Communication

5. Governance

6. Financing

7. Monitoring and Evaluation

The development of the National Policy on ICT in education was driven by a need for a standardised and coordinated deployment of ICT in education with appropriate guidance for implementing partners. The FME expects that the policy will support a rapid transformation of teaching, learning, research, and the administration of education in Nigeria. 
A corresponding National Implementation Guidelines for ICTs in Education was launched in 2019, using a similar consultative and collaborative process that involved education stakeholders across the country (Federal Ministry of Education, 2019a). The aim of the guidelines is to give clear direction to stakeholders like the FME, State Ministries of Education (SMoEs), federal capital territory, local government education authorities, education parastatals, heads of institutions and school proprietors on how to effectively deploy EdTech across all levels. The guidelines are structured around the seven focus areas defined in the national policy on ICT (Federal Ministry of Education, 2019b).

The ICT in education policy is still aspirational a year after it was launched, as very little progress has been made in translating the policy into concrete action. Sub-strategies and activities planned for year one in the implementation guidelines have not been completed (Key Informant Interview, June 1). The policy and implementation document refers to partnerships and support from NGOs, especially for teacher training and capacity development. However, often, the SMoEs do not know what kind of training they want for the teachers, or where to begin (Key Informant Interview (2), June 3). In addition to this, several of the key performance indicators and deliverables in the implementation guidelines are vague, with no explicit evidence on how they contribute to the overall strategy (Key Informant Interview, June 3).

While setting policy and standards for ICT in education are the federal government's responsibilities, the implementation of ICT policies rests with state and local governments. Although both documents suggest that SMoEs were involved in the development of the policy and implementation guidelines, there is little clarity on their roles in implementing sub-strategies and activities (Key Informant Interview, June 1). Since the launch of the national ICT for education policy and implementation guidelines, several states have been adapting and creating their own policies and strategies that take state-specific contexts and resources into consideration (Key Informant Interview, June 1). 


\section{ICT infrastructure}

At the national level, household ownership of mobile phones is high (88\%) but low for personal computers (6.4\%). Only 55\% of women aged $15-49$ own a mobile phone compared to $81 \%$ of men in the same age group (USAID, 2018). Further, only $25.7 \%$ of households can access the internet from home, this statistic should, however, be treated with caution as it may include users who access the internet several times a week and those who may only access it once within a period of several months (Central Intelligence Agency, 2020). In 2019, 54\% of adult males were mobile internet users compared to $38 \%$ of adult females (GSMA, 2020).

Table 2. Percentage of households who own a radio, television, mobile phone, computer and that have access to the internet at home

\begin{tabular}{|l|l|r|}
\hline Information and Communication Technology & Year & Percentage \\
\hline Radio & 2018 & 60.6 \\
\hline Television & 2018 & 49.1 \\
\hline Computers & 2018 & 8.4 \\
\hline Mobile phones & 2018 & 25.7 \\
\hline Access to the internet at home (\% of the population) & 2016 & 0.04 \\
\hline Fixed broadband subscriptions (per 100 people) & 2018 & 25.9 \\
\hline
\end{tabular}

Urban women and men (31\% and 55\%, respectively) are more likely than rural women and men (6\% and 25\%, respectively) to have used the internet (USAID, 2018).

Table 3. Percentage of urban and rural households with radio, television or mobile phone ${ }^{2}$

\begin{tabular}{|l|l|l|l|}
\hline & Urban & Rural & Year \\
\hline Radio & 70.9 & 51.6 & 2018 \\
\hline Television & 70.7 & 30 & 2018 \\
\hline Mobile & 94.5 & 82.1 & 2018 \\
\hline Computer & 10.8 & 2.5 & 2018 \\
\hline
\end{tabular}

1 This table draws on data from USAID (2018) and Central Intelligence Agency (2020)

${ }^{2}$ This table draws on data from USAID (2018) 
There are high disparities in access to electricity. A little under half (43.5\%) of Nigerian households do not have electricity (USAID,2018). In urban areas, 83\% of households have access to electricity compared to $39 \%$ of households in rural areas (ibid.).

\section{Figure 1. The state of EdTech Infrastructure in Nigerian public schools. ${ }^{3}$}

"Data on the state of ICT infrastructure in primary and secondary schools is not always publicly available, sometimes because they were never collected and other times because they are just not available to the public. Here in the ministry of education, there is however a general knowledge that [the] majority of the primary schools do not have electricity, internet access or computers / tablets or any devices for teaching and learning. Most of the secondary schools have electricity via connection to the national power grid or via generators. However, the electricity situation is generally bad - there are several weeks of blackout, and even when the electricity is available, the current is too low to power anything.

For schools that have generators, they are mostly reserved for the principal's office or used for practical science classes. Primary and secondary schools do not have internet access. However, over the past 10 years, there have been several projects carried out to improve access to ICT infrastructure in our state. Some of these projects include installation of solar panels to power schools, donations of computers / laptops to schools [and] CSR- (corporate social responsibility) initiatives by network providers like MTN and Glo to provide internet access to selected schools. These initiatives are mostly limited to a very few schools - sometimes one or two in the state. Usually, after a few months or years, these infrastructure begin to fail, due to lack of maintenance or adequate knowledge of use by teachers and students. For example, there are schools with few laptops / computers but no computer literate teacher to use them."

\section{Key partners and initiatives in EdTech}

This section looks at the work and roles and responsibilities of key partners with regard to EdTech in Nigeria, including federal and state governments and non-governmental agencies, as well as EdTech initiatives.

\subsection{Federal Government}

The FME has ultimate responsibility for setting a vision and an agenda for the use of educational technology. Its duties as stated in the National Policy on Information and Communication Technologies are to:

- build and encourage the development, utilisation and sustenance of the ICT manpower required to achieve an ICT-enhanced education;

- establish and sustain a common ICT platform for education at all levels;

${ }^{3}$ The source of this information was a Key Informant Interview on 5th June 2020 
- ensure and encourage Research and Development (R\&D) in ICT and ICT in education;

- engage in and encourage regular stakeholder consultations (including the private sector), sensitisation of the learning community, public awareness and inter-governmental relations to achieve a broad-based consensus on ICT in education

- $\quad$ provide appropriate legal, regulatory and security frameworks to ensure that ICT in education and the conduct of related activities are focused on achieving ICT-enhanced education;

- adopt innovative and creative financing models for ICT in education;

- use monitoring and evaluation as a veritable tool in ICT in education for tracking policy implementation, efficient service delivery and compliance.

The FME works with a number of other key federal government partners (Table 5), non-governmental organisations, proprietors of private schools and the country's 36 state ministries of education to deliver these objectives.

Table 4. Other key government partners in EdTech

\begin{tabular}{|c|c|}
\hline Ministry / Agency & Roles and responsibilities in EdTech \\
\hline $\begin{array}{l}\text { National Information } \\
\text { Technology Development } \\
\text { Agency }^{4}\end{array}$ & $\begin{array}{l}\text { - Develop e-learning systems to increase access to learning } \\
\text { opportunities for Nigerians. } \\
\text { - Contribute to the development of digital skills and } \\
\text { competencies of all learners thus preparing them for the } \\
\text { world of work. }\end{array}$ \\
\hline $\begin{array}{l}\text { Federal Ministry of } \\
\text { Communication and Digital } \\
\text { Economy }^{5}\end{array}$ & $\begin{array}{l}\text { - Contribute to the development of a digital education } \\
\text { curriculum to meet the current and future needs of the } \\
\text { digital economy. } \\
\text { - Support the integration of digital literacy and skills into the } \\
\text { national education curriculum at all levels. }\end{array}$ \\
\hline $\begin{array}{l}\text { Nigeria's Communications } \\
\text { Commission }\end{array}$ & $\begin{array}{l}\text { Promote the provision of modern, universal, efficient, } \\
\text { reliable, affordable and easily accessible communications } \\
\text { services and the widest range throughout Nigeria. } \\
\text { - Design, manage and implement a Universal Access strategy } \\
\text { and programme in accordance with the Federal } \\
\text { Government's general policy and objectives. }\end{array}$ \\
\hline
\end{tabular}

${ }^{4}$ NIDTA (2020), available at https://nitda.gov.ng/e-learning-facilities/

${ }^{5}$ Ministry of Communications and Digital Economy (2020), available at https://www.commtech.gov.ng/

${ }^{6}$ NCC (2020), available at www.ncc.gov.ng 
National Universities Commission - Department of Open and Distance Education $^{7}$
- Promote, popularise and coordinate, the deployment of e-learning tools in the delivery of university education in Nigeria.

- Set and regulate the standard of e-learning practice in the Nigerian university system (NUS).

- Facilitate and strengthen the development of institutional and professional capacity in the NUS for sustainable optimisation and deployment of e-teaching opportunities in Nigerian universities.

\subsection{State governments}

As noted earlier, though the vision and policy for ICT in education are set by the federal government, responsibility for implementing educational technology solutions rests with states and local governments. States are not given much guidance on EdTech implementation even as they currently work to introduce EdTech initiatives in response to Covid-19 school interruptions (Key Informant Interview (2), June 3). Table 6 describes two state-sponsored EdTech projects in Nigeria.

\section{Table 5. State-sponsored EdTech projects}

\begin{tabular}{|l|l|}
\hline State & Project description \\
\hline Ondo State & $\begin{array}{l}\text { This project was developed by the Ondo state ministry of } \\
\text { education. It is an e-learning portal with a virtual blackboard for } \\
\text { teachers and course content for students covering various } \\
\text { subjects. The system also has a platform for computer-based tests } \\
\text { (CBT) and a past-questions feature to help students with revisions. } \\
\text { The portal has different access levels for students, teachers, school } \\
\text { administrators and education ministry officials. }\end{array}$ \\
\hline Ogun State & $\begin{array}{l}\text { Ogun state has developed a digital classroom to provide digital } \\
\text { education to primary and secondary school students. It features } \\
\text { video lessons delivered by selected experienced teachers from } \\
\text { state schools. The platform covers subjects like mathematics, } \\
\text { elementary science and English language for lower primary, upper } \\
\text { primary and secondary school levels. }\end{array}$ \\
\hline
\end{tabular}

\footnotetext{
${ }^{7}$ National Universities Commission (2020), available at https://www.nuc.edu.ng/project/open-and-distance-education/
} 


\subsection{Non-governmental agencies}

Nigeria's education sector, and specifically, the use of educational technology, has been supported by development partners, including UNESCO, the World Bank, DFID, UNICEF, and GPE. Private organisations such as Oracle Academy, IBM, Microsoft and CISCO have also been key partners. The federal government does not have a specific provision for ICT in education in the national budget or in budget allocations to state governments (Key Informant Interview, June 1). Personnel (salary) costs account for most of a state's expenditures on education, leaving very little for allowance anything else. Some states spend up to $98 \%$ of their budgetary allocation on salaries and rely heavily on international partners and NGOs for non-salary expenditures. A list of NGO partners and EdTech start-ups supporting the growth of educational technology in Nigeria is shown in Table 7.

\subsection{EdTech initiatives}

\section{Table 6. Recent EdTech initiatives in Nigeria}

\begin{tabular}{|l|l|}
\hline Initiative & Details \\
\hline $\begin{array}{l}\text { EdoBEST and } \\
\text { EdoBEST@Home }\end{array}$ & $\begin{array}{l}\text { Overview: The EdoBEST programme is leveraging technology to } \\
\text { deliver educational transformation at scale in Edo State by } \\
\text { improving learning outcomes and streamlined management. } \\
\text { Target group: Students and teachers across all levels in Edo } \\
\text { State. } \\
\text { Technology: Learning is delivered through interactive audio } \\
\text { lessons, digital storybooks, digital self-study activity packs and } \\
\text { mobile interactive quizzes. } \\
\text { Reach / scale: 15,000 government teachers, 1,500 public primary } \\
\text { and junior secondary schools and 300,000 young people in Edo } \\
\text { state. } \\
\text { Implementing organisations: Bridge International Academies, } \\
\text { Edo State ministry of education. } \\
\text { Government partners: } \text { Edo State Government } \\
\text { Status of implementation: Ongoing }\end{array}$ \\
\hline
\end{tabular}

${ }^{8}$ EdoBEST (2020), available at http://subeb.edostate.gov.ng/ 


\begin{tabular}{|c|c|}
\hline SchoolGate $^{9}$ & $\begin{array}{l}\text { Overview: Schoolgate is one of the two online portals approved } \\
\text { by the FME for learning during the Covid-19 pandemic. It offers } \\
\text { low-cost audio-visual learning content to learners of all levels. } \\
\text { Target group: Learners of all levels } \\
\text { Technology: Online video learning materials and Edubox an } \\
\text { offline package for communities where there are no schools. } \\
\text { Reach / scale: As a federal-government-recommended resource, } \\
\text { Schoolgate is potentially reaching all school learners in Nigeria. } \\
\text { Implementing organisations: SchoolGate Nigeria } \\
\text { Government partners: FME, state ministries of education } \\
\text { Status of implementation: Ongoing }\end{array}$ \\
\hline Mobile Classroom ${ }^{10}$ & $\begin{array}{l}\text { Overview: A mobile platform which provides students access to a } \\
\text { pool of multimedia curriculum content. } \\
\text { Target group: Senior Secondary and Higher Institutions in } \\
\text { Nigeria. } \\
\text { Technology: A mobile application for students to learn with } \\
\text { phones and computers. } \\
\text { Reach / scale: As a federal-government-recommended resource, } \\
\text { Schoolgate is potentially reaching all school learners in Nigeria. } \\
\text { Implementing organisations: Mobile Classroom Nigeria } \\
\text { Government partners: FME, state ministries of education } \\
\text { Status of implementation: Ongoing }\end{array}$ \\
\hline Digistem $^{11}$ & $\begin{array}{l}\text { Overview: A pilot project that aims at increasing the digital } \\
\text { literacy skills of young people in primary and secondary schools } \\
\text { through focused STEM and digital activities. } \\
\text { Target group: Primary } 4-6 \text { students and Senior Secondary } \\
\text { Schools 1-2, teachers. } \\
\text { Technology: n/a } \\
\text { Reach/scale: 10,000+ young people. } \\
\text { Implementing organisations: STEMRES, RIMFEHT, World Bank } \\
\text { (SEPIP) } \\
\text { Government partners: Ekiti State Government } \\
\text { Status of implementation: } 2017-2019\end{array}$ \\
\hline
\end{tabular}

${ }_{9}^{9}$ SchoolGate (2020), available at https://schoolgate.ng/

${ }^{10}$ Mobile Classroom (2020), available at https://www.mobileclassroom.com.ng/

${ }^{11}$ Digitstem (2020), available at https://digistem.co/ 


\begin{tabular}{|c|c|}
\hline BDEI & $\begin{array}{l}\text { Overview: The Basic Digital Education Initiative (BDEI) is an } \\
\text { experiential-learning, computer education and STEM programme. } \\
\text { Target group: Young people in rural communities between ages } \\
\text { 8-18 } \\
\text { Technology: } n / a \\
\text { Reach / scale: The programme aims to train 500,000 public } \\
\text { school students between ages } 8-18 \text { across selected states in } \\
\text { Nigeria. } \\
\text { Implementing organisations: Microsoft, Tech4Dev } \\
\text { Government partners: } 12 \text { selected state governments } \\
\text { Status of implementation: } 2020-2022\end{array}$ \\
\hline Mavis Talking Books ${ }^{12}$ & $\begin{array}{l}\text { Overview: The Basic Digital Education Initiative (BDEI) is an } \\
\text { experiential-learning, computer education and STEM programme. } \\
\text { Target group: Young people in rural communities between ages } \\
\text { 8-18. } \\
\text { Technology: Digital books, digital pens with recorded educational } \\
\text { content. } \\
\text { Reach / scale: 18,520 students reached, } 6+\text { states in Nigeria } \\
\text { Implementing organisations: Mavis Talking Books, Cambridge } \\
\text { Education, US Embassy Abuja, Nigerian Army Language Support } \\
\text { Government partners: State ministries of education } \\
\text { Status of implementation: Ongoing }\end{array}$ \\
\hline FlexiSAF $^{13}$ & $\begin{array}{l}\text { Overview: The Basic Digital Education Initiative (BDEI) is an } \\
\text { experiential-learning, computer education and STEM programme. } \\
\text { Target group: Young people in rural communities between ages } \\
\text { 8-18 } \\
\text { Technology: A virtual classroom which offers real-time } \\
\text { collaboration, engaging online materials and assessments and } \\
\text { reporting mechanism for analysing students' performances } \\
\text { Reach / scale: } 500 \text { schools in Nigeria } \\
\text { Implementing organisations: FlexiSAF } \\
\text { Government partners: N/A } \\
\text { Status of implementation: Ongoing }\end{array}$ \\
\hline
\end{tabular}

\footnotetext{
${ }_{12}$ Mavis Education (2020), available at http://maviseducation.com/

${ }^{13}$ FlexiSAF (2020), available at https://flexisaf.com/
} 


\section{The Nigerian Government education sector response to Covid-19}

On March 19, 2020, the FME approved the closure of all academic institutions to prevent the further spread of Covid-19. The closure of schools has affected close to 46 million students throughout the country. The FME began rapidly mobilising to find ways to ensure students continue learning from home during the country's lockdown. Through a coordinated effort, the FME and the Universal Basic Education Commission established a Task-Force Team that developed the Learn at Home Programme (LHP). This programme is designed to ensure that children do not lose learning time. The Task-Force Team also mapped solutions for three potential scenarios:

- Scenario 1: Schools are closed for one month. The month would be considered a normal holiday period during which children would still be involved in completing assignments and homework activities. Proper awareness and sanitation practice would be communicated to the students.

- Scenario 2: Schools are closed for one to three months. Strategies would be launched to support ongoing learning through online and audio-visual methods.

- Scenario 3: Schools are closed for an extended period of more than three months. A structured approach to carrying out the digitisation of curricula and development of radio, TV or self-learning instructional materials based on the national curriculum would be introduced.

The FME launched the Nigeria Education Sector Covid-19 Response Strategy in collaboration with development partners and the states to provide a framework for planning, implementing and monitoring the learning interventions and solutions introduced in response to Covid-19 (Federal Ministry of Education, 2020).

In April 2020, the FME released a schedule for the use of radio and TV programmes as a means to deliver learning and teaching content to the students in the country. Several e-learning resources like SchoolGate and Mobile Classroom were also developed for students to access learning materials based on their curriculum. To support students in preparing for their government examinations (WAEC), an e-learning portal was set up to facilitate access to learning materials. The FME also collaborated with 9mobile Internet Service Provider to provide students with free data that would enable them to access e-learning resources and online course platforms.

\section{Looking ahead}

The FME's national ICT for education policy and implementation guidelines demonstrate the leadership and political will of the Nigerian government to harness the potential of digital technology in education. However, as this rapid scan has shown, there are foundational gaps that must be addressed to promote the appropriate use of EdTech in Nigeria. Weak infrastructure - poor electricity, limited internet coverage and inadequate funding continue to challenge and limit the use of educational technology in schools. 
The paucity of quality data is another major challenge to effective EdTech programme planning. Official data on the state of EdTech infrastructure in the 36 states are not publicly available. This rapid scan highlights the presence of several medium-scale, state-based EdTech initiatives. But these initiatives are not yet well integrated into the wider education system. Many have been introduced as immediate responses to the Covid-19 pandemic and may not be sustained going forward. States have also been adapting and using the national ICT for education policy to provide guidance and direction during the Covid-19 pandemic. Whether any of these efforts will be sustained going forward and after the pandemic, remains to be seen. 


\section{Further reading}

Kaye, T., Groeneveld, C., Moss, C., \& Haßler, B. (2020). Nepal "Ask me anything" Session: Responses to audience questions (EdTech Hub Helpdesk Response No. 13). EdTech Hub.

Moss, C. (2020a, January 22). 18 large-scale EdTech initiatives on our radar in 2020. The EdTech Hub.

Moss, C. (2020b, January 24). 15 EdTech research papers that we share all the time. The EdTech Hub.

Trucano, M. (2013). 10 principles to consider when introducing ICTs into remote, low-income educational environments.

https://blogs.worldbank.org/edutech/10-principles-consider-when-introducing-icts-re mote-low-income-educational-environments

\section{References}

Central Intelligence Agency. (2020). Nigeria | The World Factbook. https://www.cia.gov/library/publications/the-world-factbook/geos/ni.html

Dark, S. (2018). For children with disabilities in Nigeria, educational opportunities remain scant. Devex.

https://www.devex.com/news/for-children-with-disabilities-in-nigeria-educational-opp ortunities-remain-scant-93819

Digistem. (2020). Digistem | Home. https://digistem.co/

EdoBEST. (2020). Edo State Universal Basic Education Board - Education for all! http://subeb.edostate.gov.ng/

Federal Government of Nigeria. (2010). Nigeria Vision 20: 2020. https://www.nigerianstat.gov.ng/pdfuploads/Abridged Version of Nigeria\%20Vision\% 202020.pdf

Federal Ministry of Education (Nigeria). (2015). Nigeria: Education for All 2015 National Review.

Federal Ministry of Education (Nigeria). (2017). Education for Change: A Ministerial Strategic Plan.

Federal Ministry of Education (Nigeria). (2019a). National Implementation Guidelines for ICT in Education.

http://education.gov.ng/wp-content/uploads/2019/07/NATIONAL-IMPLEMENTATIONGUIDELINES-FOR-ICT-IN-EDUCATION-2019.pdf

Federal Ministry of Education (Nigeria). (2019b). National Policy on ICT in Education. http://education.gov.ng/wp-content/uploads/2019/08/NATIONAL-POLICY-ON-ICT-IN-E DUCATION-2019.pdf 
Federal Ministry of Education (Nigeria). (2020). Education Coordinated COVID-19 Response Strategy. https://education.gov.ng/education-coordinated-covid-19-response-strategy/

FlexiSAF. (2020). FlexiSAF | Home. https://flexisaf.com/

GSMA. (2020). Connected Women: The Mobile Gender Gap Report. https://www.gsma.com/mobilefordevelopment/wp-content/uploads/2020/05/GSMA-T he-Mobile-Gender-Gap-Report-2020.pdf

Ishaku, J., \& Oraka, O. (2019, March 27). Unbundling the 13 million out-of-school children in Nigeria. Southern Voice (Nigeria).

http://southernvoice.org/unbundling-the-13-million-out-of-school-children-in-nigeria/

Kaye, T., Groeneveld, C., Moss, C., \& Haßler, B. (2020). Nepal "Ask me anything" Session: Responses to audience questions (EdTech Hub Helpdesk Response No. 13). EdTech Hub.

Lawal, I. (2017, July 20). 65 \% of Nigerian schools lack electricity, says UN chief. The Guardian (Nigeria).

https://guardian.ng/features/65-of-nigerian-schools-lack-electricity-says-un-chief/

Mavis Education. (2020). Mavis Education | Home. Mavis Education.

http://maviseducation.com/

Ministry of Communication Technology (Nigeria). (2012). National Information and Communication Technology (ICT) Policy. https://nitda.gov.ng/wp-content/uploads/2018/07/National-ICT-Policy1.pdf

Ministry of Communications and Digital Economy (Nigeria). (2020). Ministry of Communications and Digital Economy | Home. https://www.commtech.gov.ng/

Mobile Classroom. (2020). Mobile Classroom | Home. https://www.mobileclassroom.com.ng/

Moss, C. (2020a, January 22). 18 large-scale EdTech initiatives on our radar in 2020. The EdTech Hub.

Moss, C. (2020b, January 24). 15 EdTech research papers that we share all the time. The EdTech Hub.

National Universities Commision. (2020). National Universities Commission | Open Distance \& e-Learning. https://www.nuc.edu.ng/project/open-and-distance-education/

NCC. (2020). Nigerian Communications Commission | Home. https://www.ncc.gov.ng/

Nigerian Educational Research and Development Council. (2013). National Education Policy. https://educatetolead.files.wordpress.com/2016/02/national-education-policy-2013.p $\underline{\mathrm{df}}$

NITDA. (2020). NITDA | e-Learning Facilities. https://nitda.gov.ng/e-learning-facilities/

Nwoko, C. (2015). Financing Education in Nigeria: Opportunities for Action. https://reliefweb.int/sites/reliefweb.int/files/resources/Nigeria nett.pdf 
Outhred, R., \& Turner, F. (2020). Prospective evaluation of GPE's country-level support to education.

https://www.globalpartnership.org/sites/default/files/document/file/2020-02-gpe-cou ntry-level-prospective-evaluation-Year-2-Nigeria.pdf

RISE. (2019). RISE in Nigeria: Non-technical Research Overview.

https://www.riseprogramme.org/sites/www.riseprogramme.org/files/attachments/Ni geria\%20CRT\%20non\%20tech\%20summary\%20.pdf

Sattar, S., \& Kalam Azad, A. (2019). Nigeria: A Short Update on Poverty and Shared Prosperity. World Bank.

http://documents1.worldbank.org/curated/en/636531549879664295/pdf/NIGERIA-Po verty-Briefing-Note.pdf

SchoolGate. (2020). Schoo/Gate | Home. https://schoolgate.ng/

Shamsuna Ahmed, Z. (2019). Highlights/Breakdown of the 2020 Approved Budget.

The Nation (Nigeria). (2018, February 28). Nigeria's disappointing investment in education. https://thenationonlineng.net/nigerias-disappointing-investment-education/

Trucano, M. (2013). 10 principles to consider when introducing ICTs into remote, low-income educational environments.

https://blogs.worldbank.org/edutech/10-principles-consider-when-introducing-icts-re mote-low-income-educational-environments

UNESCO. (2015). Fixing the Broken Promise of Education for All: Findings from the Global Initiative on Out-of-School Children.

UNICEF. (2020). Situation of women and children in Nigeria. https://www.unicef.org/nigeria/situation-women-and-children-nigeria

UNICEF Nigeria. (2020). Nigeria | Education. https://www.unicef.org/nigeria/education

United States Embassy in Nigeria. (2012). Nigeria Fact Sheet. https://photos.state.gov/libraries/nigeria/487468/pdfs/Nigeria\%20overview\%20Fact\% 20Sheet.pdf

USAID. (2015). Nigeria: Malaria Indicator Survey (MIS). https://dhsprogram.com/pubs/pdf/MIS20/MIS20.pdf

USAID. (2018). Nigeria Demographic and Health Survey. https://dhsprogram.com/pubs/pdf/FR359/FR359.pdf

World Bank. (2018). Nigeria: Human Capital Index Summary. https://databank.worldbank.org/data/download/hci/HCl 2pager NGA.pdf

World Bank. (2020). Nigeria | Country Profile. https://www.worldbank.org/en/country/nigeria/overview

World Data Lab. (2020). Nigeria | World Poverty Map. https://worldpoverty.io 
\#EdTechHub

List of interviews with key informants

Key Informant Interview, June 1

Key Informant Interview, June 3

Key Informant Interview, (2), June 3

Key Informant Interview (State), June 5 